\title{
Potensi Produk Cair (Oil phase dan Water phase) dari Pirolisis Mikroalga Sebagai Pengawet Makanan
}

\author{
Siti Jamilatun ${ }^{\mathrm{a}, 1, *}$, Martomo Setyawan ${ }^{\mathrm{a}, 2}$, Ilham Mufandi ${ }^{\mathrm{b}, 1}$, Arief Budiman ${ }^{\mathrm{c}, 1}$ \\ ${ }^{a}$ Program Studi Teknik Kimia, Fakultas Teknologi Industri, Universitas Ahmad Dahlan, Jl. Prof. Dr. Soepomo, Janturan, Yogyakarta, Telp \\ (0274)379418/381523, Fax (0274) 38152 \\ ${ }^{\mathrm{b}}$ Department of Mechanical Engineering, Faculty of Engineering, Khon Kaen University, Khon Kaen Thailand \\ c Jurusan Teknik Kimia, Universitas Gadjah Mada \\ ${ }^{1}$ sitijamilatun@ che.uad.ac.id*; ${ }^{2}$ martomosetyawan@ che.uad.ac.id; ${ }^{3}$ Ilhammufandi@ kkumail.com; ${ }^{4}$ abudiman@ ugm.ac.id \\ * corresponding author
}

ARTICLE INFO

Article history

Received December 05, 2019

Revised December 16, 2019

Accepted December 18, 2019

Keywords

Oil phase

Water phase

Phenol

Carbonyl

Acid

\section{ABSTRACT}

Microalgae is one of the oldest living organisms namely Thallophyta (plant lacking roots, stems, and leaves) that have chlorophyll as a pigment to mainly photosynthesis process. Microalgae as the water plant had some characteristics such as high carbohydrate, protein, and lipid content in which can be produced energy (liquid, solid, and gas) by using the pyrolysis process. The raw material in this experiment was used Spirulina platensis as the type of microalgae. The residue of Spirulina platensis was content acid, phenol, dan carbonyl in which this product liquid is potential as a food preservative. The experiment was performed by using the pyrolysis process which is equipped with a cooler (condenser) to condense the combustion vapor. Thermal decomposition was conducted in the pyrolysis reactor with a temperature of $300{ }^{\circ} \mathrm{C}, 400{ }^{\circ} \mathrm{C}, 500{ }^{\circ} \mathrm{C}$, and $600^{\circ} \mathrm{C}$ under atmospheric condition. The result indicated that the pyrolysis proses had oil phase as the top result and water phase as the bottom result. The result from $\mathrm{GC} / \mathrm{MS}$ analysis reported that the pyrolysis process on temperature of $300{ }^{\circ} \mathrm{C}$ can produce the oil phase with the phenol content of $6.7 \mathrm{wt} . \%$, acid of 33.03 wt.\%, carbonyl of 4.95 wt.\%, and Poly Aromatic Hydrocarbon (PAH) of 6.23 wt.\%, respectively. Otherwise, the pyrolysis process can produce the water phase (liquid smoke) on temperature $400{ }^{\circ} \mathrm{C}, 500{ }^{\circ} \mathrm{C}$, dan $600{ }^{\circ} \mathrm{C}$ with the phenol content of 0.22 wt.\%, acid content of 0.69-9.12 wt.\%, carbonyl content of 10.46-13.02 wt. $\%$ and PAH of 26.93-45.18 wt.\%. The superiority of preservatives from residual Spirulina platensis has a high nitrogenate content from protein decomposition (10.13-31.22 wt.\%). High protein content in food preservatives can be used as an additive compound to increase protein intake.

This is an open access article under the CC-BY-SA license.

\section{Pendahuluan}

Dari Handbook of Energy and Economic Statistics of Indonesia (HEESI) 2016 [1], didapatkan data penduduk dunia pada tahun 2017 yakni 7550 Milyar, dan akan meningkat dengan tajam pada tahun 2030 yakni 8551 Milyar. Peningkatan jumlah penduduk ini harus disikapi dengan penyediaan cadangan pangan yang cukup aman [2]. Banyak produk makanan dengan masa simpan yang cukup pendek, dalam hitungan jam atau hari. Untuk itulah perlu dicari jalan keluar bagaimana produk makanan ini dapat dijaga keawetan dengan tidak mengurangi kandungan gizi dan rasanya.

Dalam rangka untuk memenuhi kebutuhan pangan penduduk dunia, maka industri makanan dan produk turunannya harus memenuhi persyaratan keawetan, keamanan, dan kualitas pangan serta pengurangan limbah produksi pangan [3]. Salah satu proses pengawetan yang dilarang namun masih 
banyak dilakukan yaitu pengawetan makanan menggunakan zat-zat aditif [3-5]. Beberapa zat aditif yang banyak digunakan untuk pengawet makanan yang dilarang yaitu formalin dan boraks. Formalin adalah bahan kimia yang digunakan sebagai desinfektan, pembasmi serangga serta digunakan dalam industri tekstil dan kayu lapis. Bahan kimia tersebut sangat berbahaya apabila digunakan sebagai pengawet makanan. Akibat dari penggunaan formalin dapat menyebabkan kanker hingga kematian. Produsen makanan banyak menggunakan zat aditif ini dengan tujuan memperpanjang masa simpan makanan dan meningkatkan keuntungan penjualan [6, 7].

Pengawet yang aman digunakan dapat berasal dari bahan alami dan sintesis. Pengawet alami yang bisa digunakan antara lain gula tebu, gula merah, garam, kunyit, kulit kayu manis, dan cengkeh. Sedangkan pengawet sintesis antara lain asam asetat, benzoat, sulfit, propit galat, propionat, garam nitrit, dan sorbat [4].

Menurut Lingbeck, 2014 [4], pengawet alami seperti asap cair (liquid smoke) hasil dari pirolisis lignoselulosa (tempurung kelapa, kayu, limbah pertanian, dll) mengandung hemiselulosa, selulosa, dan lignin. Asap cair ini mengandung senyawa-senyawa anti mikroba, anti bakteri, dan antioksidan. Senyawa-senyawa tersebut yakni asam dan turunannya, alkohol, fenol, aldehid, karbonil, keton, dan pirimidin. Untuk itu dimungkinkan bahan baku pirolisis dapat berasal dari sumber biomassa yang lain, yakni mikroalga [8].

Dengan kekayaan alam hayati yang sangat melimpah, mikroalga adalah salah satu tumbuhan tumbuh dan dikembangkan dengan media air. Beberapa keuntungan mikroalga adalah: (i) tingkat pertumbuhannya sangat tinggi (hingga $20 \mathrm{~g}$ ganggang kering per $\mathrm{m}^{2}$ per hari), (ii) hasil per area juga tinggi, yakni 15 kali lebih tinggi dari kelapa sawit, (iii) efisiensi yang tinggi dalam hal menangkap $\mathrm{CO}_{2}$ dan konversi energi surya (8\%), (iv) tidak ada persaingan dengan pertanian pangan dan tumbuh di perairan terbuka (air laut dan kolam) dan dalam photobioreactor di lahan non-pertanian [9]. Untuk itu mikroalga sangat potensial sebagai sumber bahan baku yang sangat melimpah dan dapat diolah dengan cara pirolisis. Pirolisis adalah dekomposisi termal mikroalga tanpa adanya oksigen. Berikut Tabel 1 daftar berbagai macam jenis mikroalga dengan kandungan protein, karbohidrat, dan lipid.

Tabel 1. Jenis mikroalga dan kandungan protein, karbohidrat, dan lipid [9]

\begin{tabular}{cccc}
\hline Mikroalga & Protein (\%) & Karbohidrat (\%) & Lipid (\%) \\
\hline Snenedesmus dimorphus & $8-18$ & $21-52$ & $16-40$ \\
Scenedesmus obliquus & $50-56$ & $10-17$ & $12-14$ \\
Chlorella vulgaris & $51-58$ & $12-17$ & $14-22$ \\
Chlorella pyrenoidosa & 57 & 26 & 2 \\
Spirogyra sp. & $6-20$ & $33-64$ & $11-21$ \\
Dunaliella salina & 57 & 32 & 6 \\
Tetraselmis moculata & 52 & 15 & 3 \\
Spirulina platensis & $46-63$ & $8-14$ & $4-9$ \\
\hline
\end{tabular}

Spirulina platensis adalah jenis mikroalga dengan kandungan lipid yang sangat rendah (4-9 wt.\%), kandungan protein (46-63 wt.\%), dan karbohidrat (8-14 wt.\%) yang cukup tinggi. Setelah diekstraksi, maka akan didapatkan Spirulina platensis residue (SPR) yang hampir tidak didapatkan lipidnya. Residu inilah yang dipirolisis, hanya terjadi dekomposisi termal karbohidrat dan protein. Dengan pirolisis akan dihasilkan produk cair (oil phase dan water phase), gas, dan char. Produk cair dapat digunakan sebagai pengawet makanan karena kandungan asam, phenol, dan karbonil yang cukup tinggi. Pada pirolisis tempurung kelapa, hanya water phase (liquid smoke) saja yang digunakan sebagai pengawet pangan [4,11-12].

Keunggulan produk cair pirolisis mikroalga adalah oil phase dan water phase masing-masing berpotensi sebagai pengawet makanan dan senyawa nitrogenat yang cukup tinggi dapat digunakan sebagai asupan protein pada makanan yang diawetkan. Sedangkan produk gas dapat digunakan sebagai energi, serta produk char dapat dipakai sebagai adsorben atau soil softener [8].

Dari beberapa uraian di atas, maka sangat menarik bahwa pemanfaatan residu ekstraksi mikroalga spirulina platensis dengan cara pirolisis dapat dihasilkan produk cair (oil phase dan water phase) sebagai pengawet makanan yang aman dan sangat potensial untuk dikembangkan lebih lanjut. 


\section{Metode Penelitian}

\subsection{Bahan Baku}

Bahan baku yang digunakan pada penelitian ini adalah Mikroalga jenis Spirulina Platensis yang sudah diambil lipidnya dengan cara ektraksi dengan metanol dan heksana yang disebut dengan Spirulina Platensis Residue (SPR). Bahan baku alga diambil dari Alga Park Universitas Gadjah Mada. SPR sebelum digunakan terlebih dahulu dikeringkan pada suhu $60{ }^{\circ} \mathrm{C}$ untuk menghilangkan kadar airnya. Karakteristik bahan baku SPR dapat dilihat pada Tabel 2.

\subsection{Prosedur Penelitian}

Pada Gambar 1, menampilkan rangkaian alat untuk penelitian ini terdiri dari reaktor, kondenser, heater, akumulator gas, dan thermocouple. Adapun prosedur penelitian ditampilkan pada Gambar 2. Lima puluh (50) g SPR dimasukkan dalam reaktor, ditutup rapat dan dipanaskan. Sampel yang diuji dipanaskan dengan tingkat pemanasan konstan dari suhu kamar sampai ke suhu yang diinginkan $\left(300,400,500,600{ }^{\circ} \mathrm{C}\right)$, kemudian dijaga konstan selama 1 jam pada suhu yang diinginkan. Produk cair keluar kondensor dikumpulkan dalam akumulator, dan produk gas dikumpulkan dalam kantong gas. Produk cair yang berupa campuran dari fase minyak (fase atas) dan fase air (fase bawah), dipisahkan dengan dekantasi dan selanjutnya dianalisis menggunakan GC-MS untuk mengetahui kandungannya.

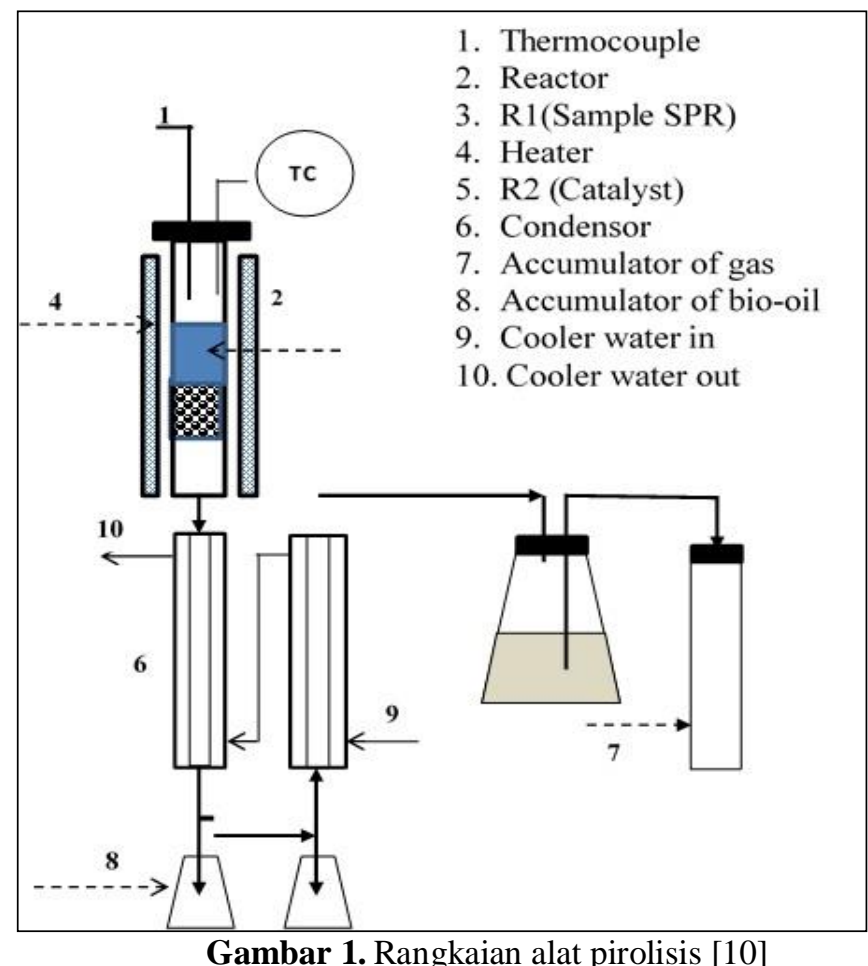

\section{Hasil dan pembahasan}

\subsection{Komposisi spirulina platensis residue (SPR)}

Pada Tabel 2 disajikan hasil analisis proximate, ultimate dari Spirulina platensis residue (SPR). Dari tabel ini dapat dilihat bahwa SPR mempunyai kandungan lipid yang rendah $(0,09$ $w t . \%)$, tinggi kandungan protein $(49,60 w t . \%)$ dan karbohidrat $(25,59 w t . \%)$. Adapun kandungan selullosa cukup tinggi (26,85 wt.\%), hemiselullosa cukup tinggi $(32,77 \mathrm{wt} . \%)$, sedangkan lignin sangat rendah $(8,82$ wt. $\%)$. 


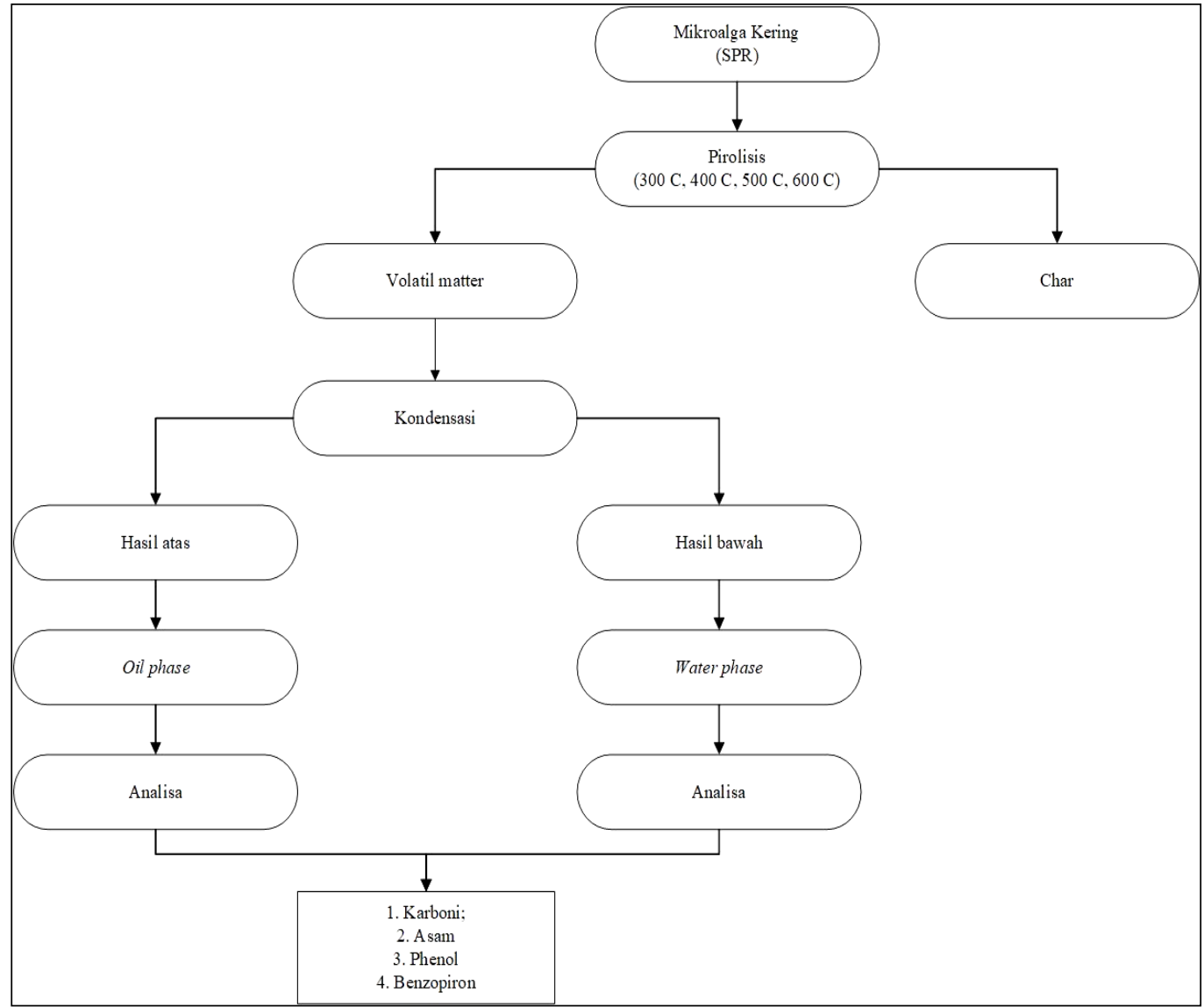

Gambar 2. Prosedur penelitian

Tabel 2. Karakteristik Spirulina platensis residue (SPR) [7]

\begin{tabular}{cc}
\hline Komponen & (SPR) \\
\hline Moisture (wt.\%) & 9,99 \\
Ash (wt.\%) & 8,93 \\
Volatiles (wt.\%) & 68,31 \\
Fixed carbon (wt.\%) & 12,77 \\
Selullosa & 26,85 \\
Hemi selullosa & 32,77 \\
Lignin & 8,82 \\
Proximate analysis (wt.\%) & \\
Lipid & 0,09 \\
Carbohydrate & 25,59 \\
Protein & 49,60 \\
Carbon & \\
Cltimate analysis $(\mathbf{w})$ & 41,36 \\
Hydrogen & 6,60 \\
Nitrogen & 7,17 \\
Oxygen & 35,33 \\
\hline
\end{tabular}

\subsection{Hubungan suhu pirolisis dengan kandungan senyawa pada minyak pirolisis (oil phase)}

Data komposisi produk cair (oil phase) dari pirolisis SPR pada suhu 300 dan $400{ }^{\circ} \mathrm{C}$ dengan 50 komponen senyawa didapatkan dari GC-MS yang disajikan pada Tabel 3 dan 4. Tabel-tabel ini berisi data peak, retention time, persentase area, nama senyawa, formula, dan komposisi kandungan senyawa pada oil phase. 
Tabel 3. Komposisi senyawa penyusun oil phase hasil GC-MS pada pirolisis $300{ }^{\circ} \mathrm{C}$

\begin{tabular}{|c|c|c|c|c|c|c|c|c|c|c|c|c|}
\hline Peak & R. Time & $\begin{array}{c}\% \\
\text { Area }\end{array}$ & Senyawa & Formula & Asam & $\begin{array}{c}\text { Al- } \\
\text { kohol }\end{array}$ & $\begin{array}{c}\text { Karbo- } \\
\text { nil }\end{array}$ & Phenol & $\begin{array}{c}\text { Al- } \\
\text { dehid }\end{array}$ & $\begin{array}{l}\text { Nitro } \\
\text { genat }\end{array}$ & $\begin{array}{c}\text { Ali- } \\
\text { fatik }\end{array}$ & PAH \\
\hline 1 & 3,038 & 2,64 & $\begin{array}{c}\text { 2-Furanmethanol (CAS) } \\
\text { Furfuryl alcohol }\end{array}$ & $\mathrm{C}_{5} \mathrm{H}_{6} \mathrm{O}_{2}$ & & 2,64 & & & & & & \\
\hline 2 & 3,485 & 1,94 & $\begin{array}{l}\text { 2-Furanmethanol (CAS) } \\
\text { Furfuryl alcohol }\end{array}$ & $\mathrm{C}_{5} \mathrm{H}_{6} \mathrm{O}_{2}$ & & 1,94 & & & & & & \\
\hline 3 & 3,633 & 0,47 & $\begin{array}{l}\text { 2-Furanmethanol (CAS) } \\
\text { Furfuryl alcohol }\end{array}$ & $\mathrm{C}_{5} \mathrm{H}_{6} \mathrm{O}_{2}$ & & 0,47 & & & & & & \\
\hline 4 & 3,874 & 2,07 & $\begin{array}{c}\text { Pyrazine, 2,6-dimethyl- } \\
\text { (CAS) 2,6- } \\
\text { Dimethylpyrazine }\end{array}$ & $\mathrm{C}_{6} \mathrm{H}_{8} \mathrm{~N}_{2}$ & & & & & & 2,07 & & \\
\hline 5 & 4,042 & 0,82 & $\begin{array}{l}\text { 3-Heptanol (CAS) 3- } \\
\text { Hydroxyheptane }\end{array}$ & $\mathrm{C}_{7} \mathrm{H}_{16} \mathrm{O}$ & & 0,82 & & & & & & \\
\hline 6 & 4,150 & 0,13 & $\begin{array}{l}\text { Propanoic acid, 2- } \\
\text { hydroxy-2-methyl-, ethyl } \\
\text { ester (CAS) Ethyl 2- } \\
\text { methyllactate }\end{array}$ & $\mathrm{C}_{6} \mathrm{H}_{12} \mathrm{O}_{3}$ & 0,13 & & & & & & & \\
\hline 7 & 4,192 & 0,27 & $\begin{array}{l}\text { 2-Butenoic acid, (E)- } \\
\text { (CAS) (E)-Crotonic acid }\end{array}$ & $\mathrm{C}_{4} \mathrm{H}_{6} \mathrm{O}_{2}$ & 0,27 & & & & & & & \\
\hline 8 & 4,433 & 0,40 & $\begin{array}{c}\text { Pyridine, 2,5-dimethyl- } \\
\text { (CAS) 2,5- } \\
\text { Dimethylpyridine }\end{array}$ & $\mathrm{C}_{7} \mathrm{H}_{9} \mathrm{~N}$ & & & & & & 0,4 & & \\
\hline 9 & 4,650 & 0,53 & $\begin{array}{l}\text { 2(3H)-Furanone, dihydro- } \\
\text { (CAS) Butyrolactone }\end{array}$ & $\mathrm{C}_{4} \mathrm{H}_{6} \mathrm{O}_{2}$ & & & 0,53 & & & & & \\
\hline 10 & 5,008 & 0,24 & $\begin{array}{l}\text { Acetamide (CAS) } \\
\text { Ethanamide }\end{array}$ & $\mathrm{C}_{2} \mathrm{H}_{5} \mathrm{NO}$ & & & & & & 0,24 & & \\
\hline 11 & 5,492 & 0,12 & $\begin{array}{c}\text { 2-Butenoic acid (CAS) } \\
\text { Crotonic acid }\end{array}$ & $\mathrm{C}_{4} \mathrm{H}_{6} \mathrm{O}_{2}$ & 0,12 & & & & & & & \\
\hline 12 & 5,692 & 0,69 & $\begin{array}{c}\text { 2-Butenoic acid (CAS) } \\
\text { Crotonic acid }\end{array}$ & $\mathrm{C}_{4} \mathrm{H}_{6} \mathrm{O}_{2}$ & 0,69 & & & & & & & \\
\hline 13 & 6,056 & 3,37 & $\begin{array}{l}\text { 2-Butenoic acid, (E)- } \\
\text { (CAS) (E)-Crotonic acid }\end{array}$ & $\mathrm{C}_{4} \mathrm{H}_{6} \mathrm{O}_{2}$ & 3,37 & & & & & & & \\
\hline 14 & 6,247 & 4,03 & $\begin{array}{l}\text { 2-Butenoic acid (CAS) } \\
\text { Crotonic acid }\end{array}$ & $\mathrm{C}_{4} \mathrm{H}_{6} \mathrm{O}_{2}$ & 4,03 & & & & & & & \\
\hline 15 & 6,486 & 2,20 & $\begin{array}{l}\text { 2-Butenoic acid, (E)- } \\
\text { (CAS) (E)-Crotonic acid }\end{array}$ & $\mathrm{C}_{4} \mathrm{H}_{6} \mathrm{O}_{2}$ & 2,2 & & & & & & & \\
\hline 16 & 7,250 & 0,34 & $\begin{array}{c}\text { Propanediamide (CAS) } \\
\text { Malonamide }\end{array}$ & $\mathrm{C}_{3} \mathrm{H}_{6} \mathrm{~N}_{2} \mathrm{O}_{2}$ & & & & & & 0,34 & & \\
\hline 17 & 7,351 & 0,42 & $\begin{array}{l}\text { Pentanoic acid, 4-methyl- } \\
\text { (CAS) 4-Methylvaleric } \\
\text { acid }\end{array}$ & $\mathrm{C}_{6} \mathrm{H}_{12} \mathrm{O}_{2}$ & 0,42 & & & & & & & \\
\hline 18 & 8,056 & 2,51 & $\begin{array}{l}\text { Hexanamide (CAS) } \\
\text { Caproamide }\end{array}$ & $\mathrm{C}_{6} \mathrm{H}_{13} \mathrm{NO}$ & & & & & & 2,51 & & \\
\hline 19 & 8,477 & 1,18 & $\begin{array}{c}\text { Cyclohexane, } 1,4- \\
\text { bis(ethoxymethyl)- (CAS) } \\
1,4- \\
\text { DIETHOXYMETHYLC } \\
\text { YCLOHEXANE }\end{array}$ & $\mathrm{C}_{12} \mathrm{H}_{24} \mathrm{O} 2$ & & 1,18 & & & & & & \\
\hline 20 & 8,835 & 1,73 & $\begin{array}{l}\text { 2,6-Pyridinediamine } \\
\text { (CAS) 2,6- } \\
\text { Diaminopyridine }\end{array}$ & $\mathrm{C}_{5} \mathrm{H}_{7} \mathrm{~N}_{3}$ & & & & & & 1,73 & & \\
\hline 21 & 9,142 & 024 & $\begin{array}{l}\text { 2-Pyridinamine, 6- } \\
\text { methyl-(CAS) 2-Amino- } \\
\text { 6-picoline }\end{array}$ & $\mathrm{C}_{6} \mathrm{H}_{8} \mathrm{~N}_{2}$ & & & & & & 0,24 & & \\
\hline 22 & 9,597 & 481 & $\begin{array}{l}\text { 2-Pyrrolidinone (CAS) } \\
\text { Pyrrolidone }\end{array}$ & $\mathrm{C}_{4} \mathrm{H}_{7} \mathrm{NO}$ & & & & & & 4,81 & & \\
\hline 23 & 10,147 & 269 & $\begin{array}{c}\text { Pentanamide, 4-methyl- } \\
\text { (CAS) 4- } \\
\text { Methylvaleramide }\end{array}$ & $\mathrm{C}_{6} \mathrm{H}_{13} \mathrm{NO}$ & & & & & & 2,69 & & \\
\hline 24 & 10,300 & 315 & $\begin{array}{c}\text { 2-Furanmethanol, } \\
\text { tetrahydro- (CAS) } \\
\text { Tetrahydrofurfuryl } \\
\text { alcohol }\end{array}$ & $\mathrm{C}_{5} \mathrm{H}_{10} \mathrm{O}_{2}$ & & 3,15 & & & & & & \\
\hline 25 & 10,887 & 222 & $\begin{array}{c}1,1- \\
\text { Cyclopropanedicarbonitril } \\
\text { e, 2-methyl-2-pentyl- } \\
\text { (CAS) 2-PENTYL-2- } \\
\text { METHYL-1,1- } \\
\text { CYCLOPROPANEDICA } \\
\text { RBONITRILE }\end{array}$ & $\mathrm{C}_{11} \mathrm{H}_{16} \mathrm{~N}_{2}$ & & & & & & 1,73 & & \\
\hline 26 & 11,659 & 10,85 & $\begin{array}{c}\text { 2-Propenoic acid, 2- } \\
\text { methyl-, ethyl ester (CAS) } \\
\text { Ethyl methacrylate }\end{array}$ & $\mathrm{C}_{6} \mathrm{H}_{10} \mathrm{O}_{2}$ & & & & & & 0,24 & & \\
\hline 27 & 12,317 & 3,83 & $\begin{array}{l}\text { Indolizine (CAS) } \\
\text { Indolizin }\end{array}$ & $\mathrm{C}_{8} \mathrm{H}_{7} \mathrm{~N}$ & & & & & & & & 3.83 \\
\hline 28 & 12,651 & 1,95 & $\begin{array}{l}\text { Benzeneacetonitrile } \\
\text { (CAS) Benzyl cyanide }\end{array}$ & $\mathrm{C}_{8} \mathrm{H}_{7} \mathrm{~N}$ & & & & & & 2,69 & & \\
\hline 29 & 13,126 & 6,70 & $\begin{array}{c}\text { Phenol, 2-methoxy-3-(2- } \\
\text { propenyl)- (CAS) Phenol, } \\
\text { 3-allyl-2-methoxy- (CAS) } \\
\text { 3-Allylguaiacol }\end{array}$ & $\mathrm{C}_{10} \mathrm{H}_{12} \mathrm{O}_{2}$ & & & & 6,7 & & & & \\
\hline 30 & 13,690 & 2,14 & $\begin{array}{l}\text { Spiro[4.4]nonan-2-one } \\
\text { (CAS) SPIRO }(4,4) \\
\text { NONANE-2-ONE }\end{array}$ & $\mathrm{C}_{9} \mathrm{H}_{14} \mathrm{O}$ & & & & & & & & 2.14 \\
\hline
\end{tabular}




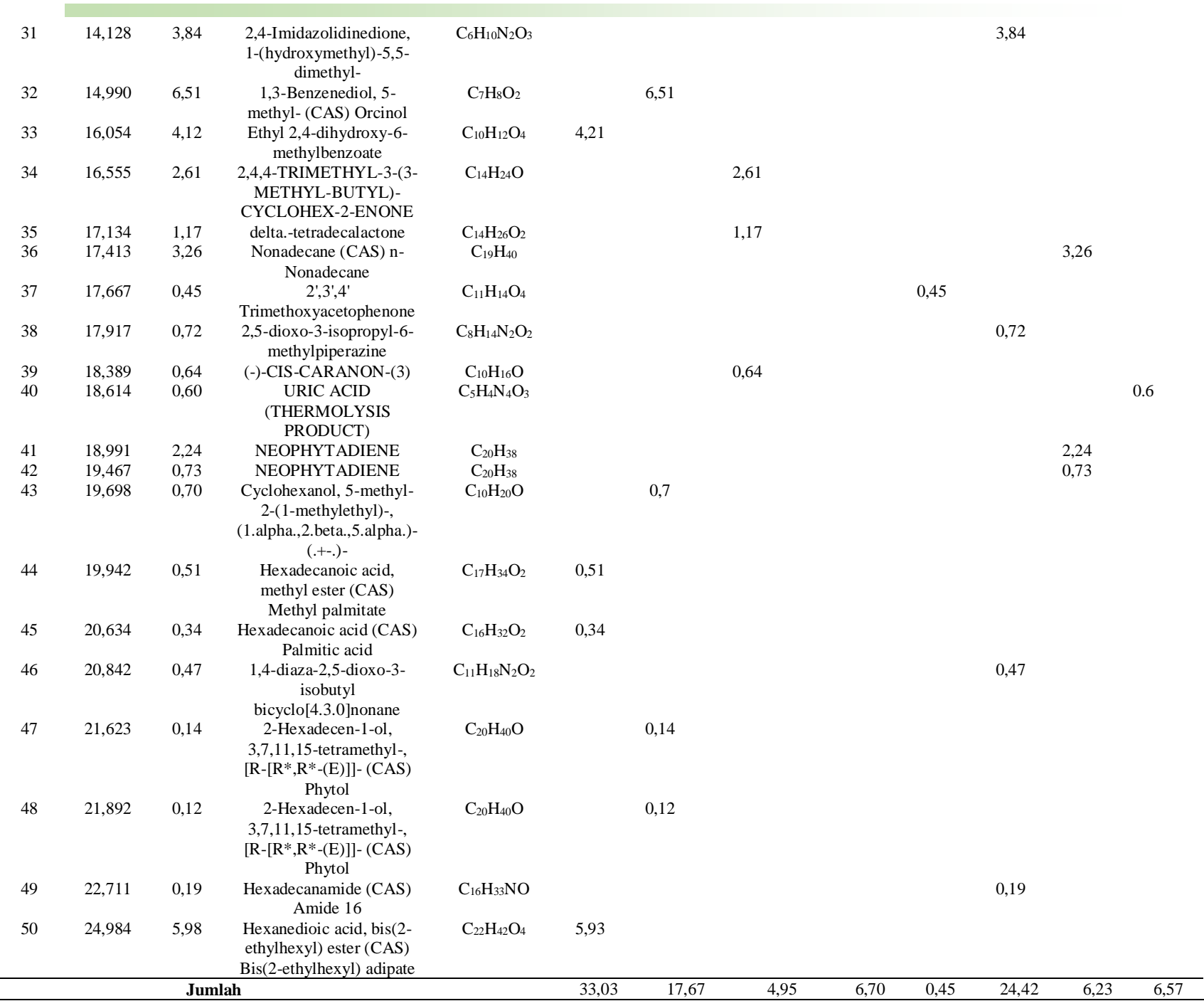

Dari Tabel 3 diperoleh data oil phase mengandung asam (33,03 wt.\%), karbonil (4,95 wt.\%) yang cukup memenuhi syarat sebagai pengawet makanan, akan tetapi kandungan phenol cukup kecil (6,70 wt.\%). Kandungan senyawa poliaromatik hidrokarbon (PAH) sebesar 6,57 wt.\%. PAH adalah senyawa yang bersifat karsinogenik dan tidak dikehendaki dalam pengawet makanan. Kandungan senyawa nitrogenat yang cukup tinggi $(24,42 \mathrm{wt} . \%)$ berpotensi untuk tambahan asupan protein pada makanan yang diawetkan.

Tabel 4. Komposisi senyawa penyusun oil phase hasil GC-MS dari pirolisis $400{ }^{\circ} \mathrm{C}$

\begin{tabular}{|c|c|c|c|c|c|c|c|c|c|c|c|c|}
\hline Peak & R. Time & $\begin{array}{c}\% \\
\text { Area }\end{array}$ & Senyawa & Formula & Asam & $\begin{array}{c}\text { Al- } \\
\text { kohol }\end{array}$ & $\begin{array}{c}\text { Karbo- } \\
\text { Nil }\end{array}$ & Phenol & $\begin{array}{c}\text { Al- } \\
\text { dehid }\end{array}$ & $\begin{array}{l}\text { Nitro } \\
\text { genat }\end{array}$ & $\begin{array}{l}\text { Ali- } \\
\text { fatik }\end{array}$ & PAH \\
\hline 1 & 3,075 & 5,70 & $\begin{array}{c}10.45 \text { 8-Nonynoic acid } \\
\text { (CAS) }\end{array}$ & $\mathrm{C}_{9} \mathrm{H}_{14} \mathrm{O}_{2}$ & 5,7 & & & & & & & \\
\hline 2 & 3,298 & 2,67 & 7.05 Styrene & $\mathrm{C}_{8} \mathrm{H}_{8}$ & & & & & & & & 2,67 \\
\hline 3 & 3,656 & 8,25 & $\begin{array}{l}\text { 18.32 2-Furanmethanol } \\
\text { (CAS) Furfuryl alcohol }\end{array}$ & $\mathrm{C}_{5} \mathrm{H}_{6} \mathrm{O}_{2}$ & & 8,25 & & & & & & \\
\hline 4 & 3,717 & 476 & $\begin{array}{l}\text { 10.66 2-Furanmethanol } \\
\text { (CAS) Furfuryl alcohol }\end{array}$ & $\mathrm{C}_{5} \mathrm{H}_{6} \mathrm{O}_{2}$ & & 4,76 & & & & & & \\
\hline 5 & 4,025 & 147 & $\begin{array}{c}9.05 \text { 1H-Pyrrole, } 2,3- \\
\text { dimethyl- (CAS) 2,3- } \\
\text { DIMETHYLPYRROLE }\end{array}$ & $\mathrm{C}_{6} \mathrm{H}_{9} \mathrm{~N}$ & & & & & & 1,47 & & \\
\hline 6 & 4,790 & 066 & $\begin{array}{l}5.98 \text { 2(3H)-Furanone, } \\
\text { dihydro- (CAS) } \\
\text { Butyrolactone }\end{array}$ & $\mathrm{C}_{4} \mathrm{H}_{6} \mathrm{O}_{2}$ & & & 0,66 & & & & & \\
\hline 7 & 6,158 & 073 & $\begin{array}{l}\text { 6.98 Ethanone, 1-(1H- } \\
\text { pyrrol-2-yl)- (CAS) 2- } \\
\text { Acetylpyrrole }\end{array}$ & $\mathrm{C}_{6} \mathrm{H}_{7} \mathrm{NO}$ & & & & & & 0,73 & & \\
\hline 8 & 6,442 & 274 & $\begin{array}{l}\text { 17.22 Ethanone, 1-(1H- } \\
\text { pyrrol-2-yl)- (CAS) 2- } \\
\text { Acetylpyrrole }\end{array}$ & $\mathrm{C}_{6} \mathrm{H}_{7} \mathrm{NO}$ & & & & & & 2,74 & & \\
\hline 9 & 6,724 & 145 & $\begin{array}{l}\text { 9.27 Ethanone, 1-(1H- } \\
\text { pyrrol-2-yl)- (CAS) 2- } \\
\text { Acetylpyrrole }\end{array}$ & $\mathrm{C}_{6} \mathrm{H}_{7} \mathrm{NO}$ & & & & & & 1,45 & & \\
\hline 10 & 8,508 & 072 & 10.92 Phenol, 4-methyl- & $\mathrm{C}_{7} \mathrm{H}_{8} \mathrm{O}$ & & & & 0,72 & & & & \\
\hline
\end{tabular}




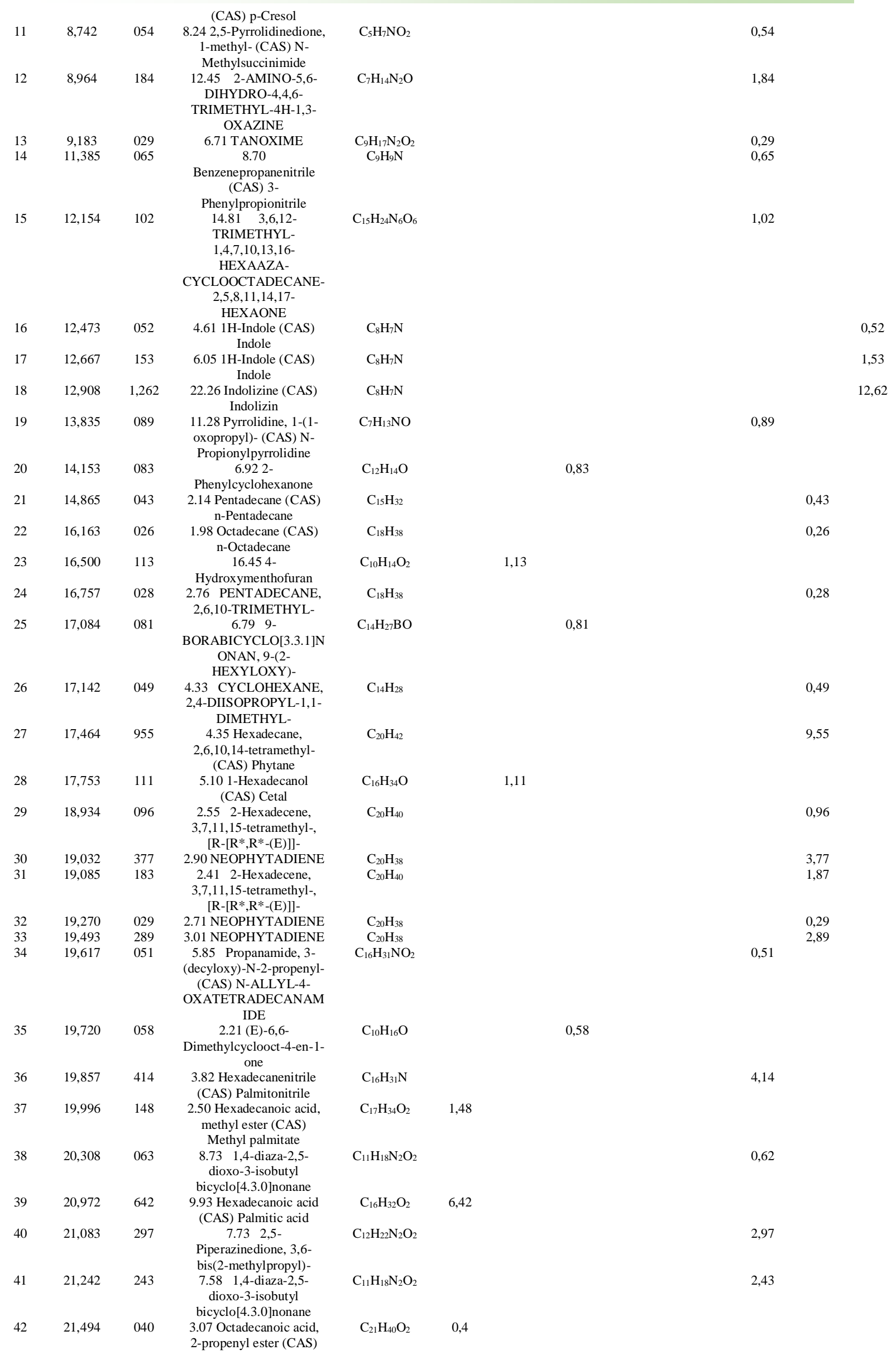




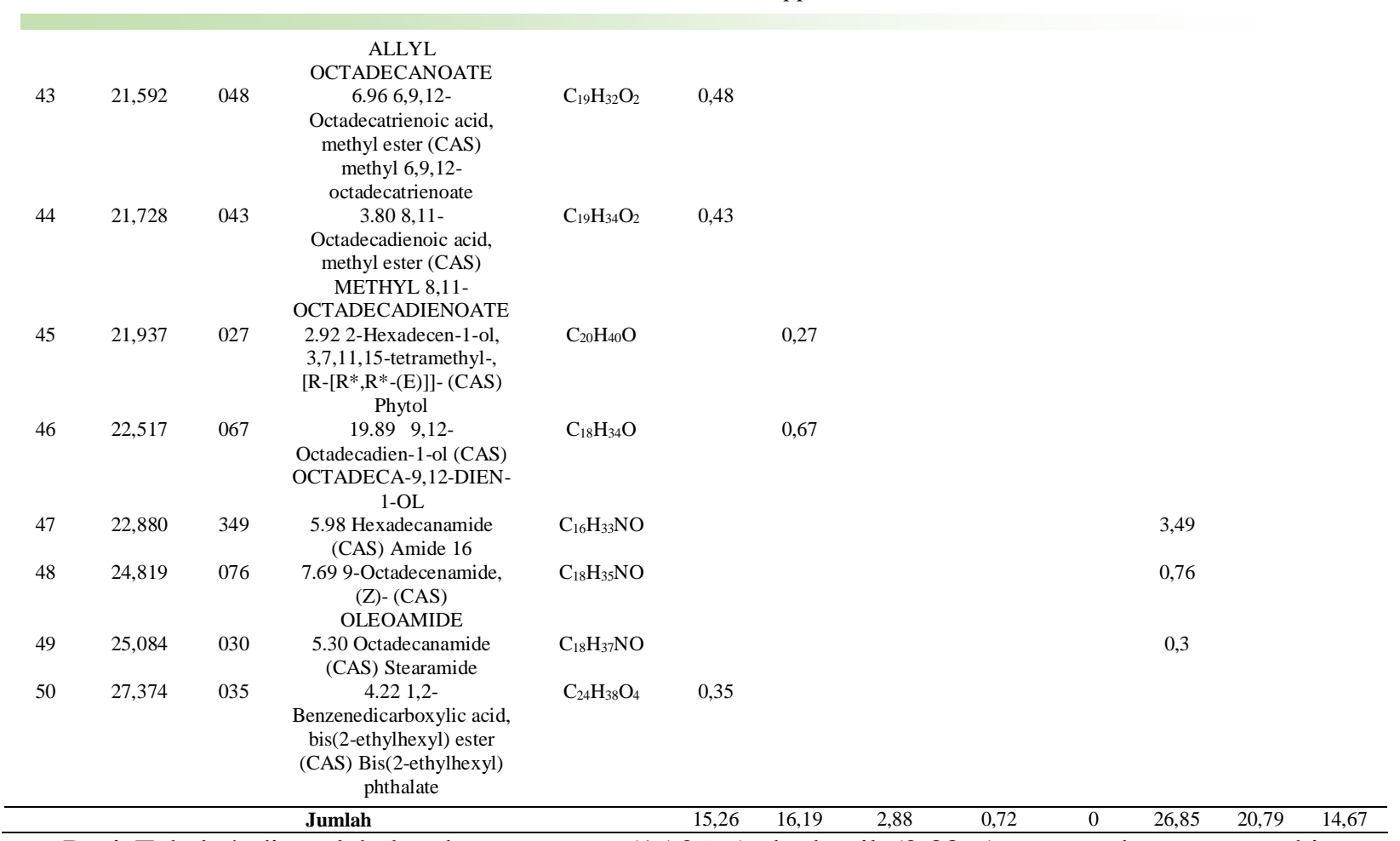

Dari Tabel 4 diperoleh kandungan asam (15,26\%), karbonil $(2,88 \%)$ yang cukup memenuhi syarat sebagai pengawet makanan, akan tetapi kandungan phenol sangat kecil $(0,72 \%)$. Kandungan senyawa poliaromatik hidrokarbon $(\mathrm{PAH})$ sebesar $14,67 \%$ bersifat karsinogenik dan tidak dikehendaki dalam pengawet makanan. Kandungan senyawa nitrogenat yang cukup tinggi $(26,85 \%)$ dapat ditambahkan pada makanan yang diawetkan.

Secara garis beras pengelompokan senyawa pada variasi suhu 500 dan $600{ }^{\circ} \mathrm{C}$ dapat dilakukan dengan cara yang sama pada suhu 300 dan $400{ }^{\circ} \mathrm{C}$, disajikan pada Tabel 5 .

Tabel 5. Komponen penyusun minyak pirolitik pirolisis SPR pada berbagai macam suhu

\begin{tabular}{cccccc}
\hline Suhu, ${ }^{\mathbf{0}} \mathbf{C}$ & Asam, $\%$ & Karbonil, \% & Phenol, \% & PAH, \% & Nitrogenat, \% \\
\hline 300 & 33,03 & 4,95 & 6,7 & 6,57 & 24,42 \\
400 & 15,26 & 2,88 & 0,72 & 14,67 & 26,85 \\
500 & 5,99 & 0,39 & 0 & 13,06 & 28,61 \\
600 & 14,40 & 1,04 & 0 & 16,60 & 10,13 \\
\hline
\end{tabular}

Dari Tabel 5 dapat dilihat bahwa komponen penyusun pengawet makanan yang potensial didapatkan pada pirolisis $300{ }^{\circ} \mathrm{C}$, dimana kandungan asam (33,03\%), karbonil (4,95\%), phenol $(6,7 \%)$ dan PAH paling rendah $(6,57 \%)$ yang cukup memenuhi syarat sebagai pengawet makanan. Sedangkan pada suhu pirolisis 400,500 , dan $600{ }^{\circ} \mathrm{C}$ tidak didapatkan phenol, dan kandungan karbonil sangat rendah. Namun demikian, hampir semua suhu pirolisis mengandung senyawa nitrogenat yang cukup tinggi, yakni pada kisaran $10,13-28,61 \%$. Senyawa nitrogenat hasil pirolisis protein ini berpeluang sebagai asupan penambah protein pada makanan yang diawetkan.

Dari Tabel 5 dapat dicermati kandungan $\mathrm{PAH}$, semakin tinggi suhu pirolisis maka PAH akan mengalami peningkatan dari 6,57\% $\left(300{ }^{\circ} \mathrm{C}\right)$ menjadi $16,60 \%\left(600{ }^{\circ} \mathrm{C}\right)$. Kandungan PAH dapat dihilangkan dengan penjerapan menggunakan arang aktif [5,7]. Jamilatun dkk. (2015) telah berhasil menurunkan PAH hingga 0\% dengan arang aktif dari tempurung kelapa [5].

\subsection{Hubungan suhu pirolisis dengan kandungan senyawa penyusun water phase (liquid smoke)}

Hubungan suhu pirolisis dengan komponen penyusun asap cair (liquid smoke) dari hasil GC-MS ditampilkan pada Tabel 6. Dari tabel dapat dicermati komponen penyusun asap cair pirolisis SPR pada suhu 400-600 ${ }^{\circ} \mathrm{C}$ dengan jumlah asam relatif rendah $(0,69-9,12 \%)$, karbonil (keton dan aldehid) cukup tinggi (10,46-13,02 wt.\%), phenol 0,22 wt.\% dan PAH cukup tinggi (26,93-45,18 wt.\%). Dengan pertimbangan jumlah komponen asam, karbonil, phenol dan PAH, maka fungsi asap cair sebagai anti bakteri tidak maksimal. 
Tabel 6. Komponen penyusun asap cair hasil pirolisis SPR pada suhu 400, 500, dan $600{ }^{\circ} \mathrm{C}$

\begin{tabular}{cccc}
\hline Komponen & $\mathbf{4 0 0}^{\circ} \mathbf{C}$ & $\mathbf{5 0 0}^{\circ} \mathbf{C}$ & $\mathbf{6 0 0}^{\circ} \mathbf{C}$ \\
\hline Asam & 9,12 & 0,69 & 3,79 \\
Alkohol & 23,3 & 28,28 & 1,58 \\
Keton & 10,46 & 13,02 & 12,86 \\
Aldehid & 0 & 4,67 & 0 \\
Phenol & 0 & 0,22 & 0 \\
Nitrogenat & 8,03 & 14,31 & 7,47 \\
Alifatik & 1,64 & 2,82 & 2,18 \\
Aromatik & 1,21 & 0 & 0 \\
$\mathrm{O}_{2}$ & 0 & 9,03 & 26,2 \\
PAH & 45,18 & 26,93 & 28,79 \\
\hline
\end{tabular}

Menurut Girard, 1992 [12], cita rasa dipengaruhi oleh fenol, asam, dan karbonil. Warna dipengaruhi oleh karbonil, sedangkan daya simpan (anti bakteri) ditentukan oleh fenol, asam, dan formaldehid, adapun ketahanan tekstur oleh formaldehid. Kombinasi antara asam, karbonil dan phenol akan lebih maksimal sebagai pengawet, flavour, warna, dan tekstur. Kandungan poliaromatik hidrokarbon (PAH) yang ditemukan pada asap cair dapat dihilangkan dengan penjerapan menggunakan arang aktif, hal ini dapat diartikan bahwa produk cair pirolisis mikroalga SPR aman jika digunakan sebagai pengawet makanan [5].

\section{Kesimpulan}

Dari penelitian yang telah dilakukan dapat diambil kesimpulan bahwa, Spirulina platensis residue berpotensi sebagai bahan baku pembuatan pengawet makanan dengan proses pirolisis. Produk oil phase pada suhu $300{ }^{\circ} \mathrm{C}$ dihasilkan minyak pirolitik yang paling baik dengan kandungan asam $(33,03 \%)$, karbonil $(4,95 \%)$, phenol $(6,7 \%)$ dan dengan kandungan PAH paling rendah, yakni $6,57 \%$. Kandungan senyawa nitrogenat pada minyak pirolitik yang cukup tinggi $(10,13-31,22 \%)$ pada proses pirolisis berpotensi sebagai bahan aditif protein pada makanan yang diawetkan. Asap cair yang dihasilkan pada pirolisis SPR suhu $400{ }^{\circ} \mathrm{C}, 500{ }^{\circ} \mathrm{C}$, dan $600{ }^{\circ} \mathrm{C}$ mempunyai kandungan asam pada kisaran $0,69-9,12 \%$, karbonil $10,46-13,02 \%$, phenol $0,22 \%$, dan nitrogenat 7,47-14,31\%. Jika dibandingkan antara minyak pirolitik dan asap cair, maka minyak pirolitik pada suhu pirolisis $300{ }^{\circ} \mathrm{C}$ lebih berpotensi sebagai pengawet makanan.

\section{Ucapan Terimakasih}

Peneliti mengucapkan terimakasih atas bantuan pendanaan penelitian melalui skim Penelitian Hibah Bersaing dana internal melalui Lembaga Penelitian dan Pengabdian Kepada Masyarakat Universitas Ahmad Dahlan Yogyakarta.

\section{Daftar Pustaka}

[1] Handbook of Energy and Economic Statistics of Indonesia (HEESI), 2016.

[2] Jamilatun, S., Sumiyati, Y., Handayani, R.N., "Pengambilan Glukosa dari Tepung Biji Nangka dengan Cara Hidrolisis Enzimatik Kecambah Jagung," Prosiding Seminar Nasional Rekayasa Kimia dan Proses, Yogyakarta, 2004.

[3] Maga, J.A., "Smoke in Food Processing," CRC Press, Boca Raton, Florida, 1988.

[4] Lingbeck, J.M., Cordero, P., O'Bryan, C.A., and Johnson, M.G., Ricke, S.C. and Crandall, P.G., "Functionality of liquid smoke as an all-natural antimicrobial in food preservation," Meat Sci, 97, 197206, 2014

[5] Jamilatun, S. dan Salamah, S., "Peningkatan Kualitas Asap Cair dengan Menggunakan Arang Aktif," SNTT FGDT 2015, Universitas Muhammadiyah Surakarta, 2015.

[6] Jamilatun, S., Aslihati, L. dan Suminar, E.W., "Pengaruh perendaman ikan nila dengan asap cair (liquid smoke) terhadap daya simpan," Prosiding Semnastek 2016, 2016.

[7] Jamilatun, S. and Salamah, S., "Pemanfaatan Asap Cair Food Grade yang Dimurnikan dengan Arang Aktif sebagai Pengawet Ikan Nila,” Eksergi, 14 (2), 29-34, 2017. 
[8] Jamilatun, S., Budhijanto, Rochmadi, Yuliestyan, A. and Budiman, A., "Valuable Chemicals Derived from Pyrolysis Liquid Products of Spirulina platensis Residue,” Indones. J. Chem., 19 (3), 703 - 711 , 2019.

[9] Dragone, G., Fernandes, B., Vicente, A., and Teixeira, J.A., "Third generation biofuels from microalgae," In: Vilas AM, editor. Current research, technology and education topics in Appl. Microbiol. Biot., Badajoz: Formatex Research Center; pp.1355-66, 2010.

[10]Jamilatun, S., Budhijanto, Rochmadi and Budiman, A., "Non-catalytic slow pyrolysis of Spirulina platensis residue for production of liquid biofuel,” Int. J. Renew. Energy Res., 7(4), 1901-1908, 2017.

[11]Darmadji, Purnama, “Optimasi Pemurnian asap Cair dengan Metoda Redestilasi Jurnal Teknologi dan Industri Pangan,” Vol.XIII, No.3, 2002.

[12] Girrard, J.P., “Technology of Meat and Meat Products,” Ellis horwood, New York, 1992.

[13]J. M. Lingbeck, P. Cordero, C. A. O’Bryan, M. G. Johnson, S. C. Ricke, and P. G. Crandall, "Functionality of liquid smoke as an all-natural antimicrobial in food preservation," Meat Sci., vol. 97, no. 2, pp. 197-206, 2014.

[14]L. Singh, J. G. Varshney, and T. Agarwal, "Polycyclic aromatic hydrocarbons formation and occurrence in processed food," Food Chem., vol. 199, pp. 768-781, 2016. 